\title{
Research on the Driving Factors of Corporate and Loyalty Program Partnerships
}

\author{
Min Tian* and Ying Qin \\ School of Economics and Management, Xi'an Technological University, Xi'an, 710021
}

tianmin0@163.com,1510346782@qq.com

Keywords: Driving Factors; Reward Programs; Loyalty Program Partnerships; Mutually Beneficial

\begin{abstract}
With increased liberalization in markets, the intensity of competition has increased amongst all of companies, such as bank industry and air carriers. These companies have responded to the competitive pressure in many ways, one of which has been the formation of Loyalty Program Partnerships. The main goal of the alliance is that all businesses can benefit from it. This paper focuses on four factors that drive the companies join the Loyalty Program Partnerships. These are political factor, economic factor, strategic development factor, competitive factor. We expect to give some advises to company who is planning join the Loyalty Program Partnerships
\end{abstract}

\section{Introduction}

Loyalty Program Partnerships is also called Coalition Loyalty Program, it is a new kind of integral relationship marketing program. It is based on business and consumers to join the Alliance, there are two or more business organizations comes together implementation of joint loyalty program to achieve shared customers, mutual recognition of loyalty program, and ultimately it is a marketing tool of mutually beneficial.

Loyalty program partnerships becoming a popular means of relationship marketing because it can bring many benefits to the participants, it is reported that more than half of US households have loyalty cards, the phenomenon of domestic is that lots of consumers have several membership cards, these membership cards bring the burden on customer, so loyalty program partnerships enterprises integration alliance will integrate the membership cards to solve the drawbacks of the loyalty programs.

With the diversification of development of information technology and consumer demand, the Loyalty program partnerships has become increasingly well known and recognized, and gradually extended from the initial aviation, telecommunications, finance and retail to all walks of life, including the most representative of the aviation field, such as "Sky Team", banks and airline credit cards issued jointly shared points system.

In theory, the loyalty program partnerships also attracted the attention of scholars, many scholars focused on it. Katherine N. Lemon and Florian v. Wangenheim (2009) develop a dynamic model of cross-buying across loyalty program partnerships. They identify a reinforcing mechanism that operates when loyalty program partnerships are operating effectively [1]. Jan H. Schumann, Nancy V. Wünderlich and Heiner Evanschitzky (2014) show that a program partner deemed responsible for a service failure suffers negative customer responses through using data from a retail context. They find that when customers perceive the program's special treatment benefits as low, direct and indirect spillover effects occur, such that a service failure by one program partner has a negative effect on customer loyalty toward the program itself [2]. Il Gu Yi, Hyang Min Jeong and Woosuk Choi (2014) report that the two main activities of a loyalty program, earning and redemption of points, exhibit very different behaviors. They also found that as customers become older from their early 20's, both male and female customers increase their earning and redemption activities until they arrive at the turning points, beyond which both activities decrease [3]. Moo Yeob Lee, Ann Sung Lee and So Young Sohn (2013) study OKCashbag, the largest coalition loyalty program in Korea, offers a number of benefits such as sharing customer data with participating firms and cross-selling. They find there is great value in utilizing information pertaining to coalition loyal 
patrons. They propose how to create necessary summary information by reducing the dimension of coalition transaction data [4].

In China, Loyalty Program Partnerships is used widespread, such as commercial banks and other companies launched a joint credit card, one customer can earning points at airline and car rental companies and hotel with one membership card. In recent years, Chinese scholars have begun to focus on research Loyalty Program Partnerships. Their studies were from the perspective of consumers. However, the company is main subject in Loyalty Program Partnerships, the leader of corporate decide whether they join the alliance. Why the company joins the Loyalty Program Partnerships, what are the driving factors, all of these questions need be answered. It is very important to research the driving factors of corporate join Loyalty Program Partnerships; it will give corporate theory suggestion to make decision in Loyalty Program Partnerships.

\section{Literature Review}

In order to understand why the business join the Loyalty Program Partnerships, what kind of Loyalty Program Partnerships they join easier. We first review the literature of Loyalty Program Partnerships and the factors influence the corporates join the Loyalty Program or Loyalty Program Partnerships.

Katherine N. Lemon and Florian v. Wangenheim (2009) find that customer usage of the core service (and satisfaction with the core service) influences customer cross-buying from loyalty program partners. This cross-buying behavior then reinforces the customer's relationship with the core service, as cross-buying positively influences future purchases of the core service-when the fit of the loyalty partner with the core service is strong [1]. Kevin Goh and Mark Uncles (2003) explore the impact of global alliances from the consumer perspective, global alliances offer at least four main benefits to operators: (a) market access to overcome restrictions over route access and airline ownership imposed by national governments; (b) cost reductions and economies of scale, scope and density; (c) coordinated schedules and prices to optimize the demand for, and capacity of, each flight; and (d) opportunities to reshape industry structure and to raise barriers against new entrants[5]. Sergio G. Lazzarini and Ibmec São Paulo (2007) find that membership benefits are greatest in multiple-partner alliances involving large aggregate traffic and for carriers contributing with a large portion of the group's capacity. They also find that carriers bilaterally linked with key players of such groups are able to increase their operational performance even if they do not belong to any explicit multiple-partner alliances [6]. S.C. Morrish and R.T. Hamilton (2002) examines some 15 years of alliance experience and finds no conclusive evidence that alliance membership has yielded monopoly profits to the airlines. Improvements in terms of load factors and general productivity levels have, for the most part, been accompanied by fare reductions of similar magnitude, resulting in only modest gains to the carriers [7].

Why the corporate join the Loyalty Program or Loyalty Program Partnerships? A Bissessur and F Alamdari (1998) suggests that the main factors ensuring the alliances' operational success are: the partners' network size and their compatibility, the frequency of service between the hubs of the partners, the flight connection time at the hub and the level of competition on their network[8]. Peng Li (2014) Summarize there are six aspects are the main factors consumers to participate in Loyalty Program Partnerships, such as consumer perceived benefits, perceived complexity, perceived risk, attitude, subjective norm, demographic variables[9]. Chao ran Chen (2014) find that service of credit card have a large gap between Chinese commercial banks and overseas commercial banks, we need to further enhance through clearing earning points rule and broaden redemption channels [10].

\section{The Driving Factors of Corporate Join the Loyalty Program Partnerships}

Companies choose whether to join the Loyalty Program Partnerships is influenced by many factors, especially in China, many state-controlled enterprises due to the special status, the government-led obvious traces. We analyzed four driving factors affect the decision to join the Loyalty Program 
Partnerships. These four factors are: political factor, economic factor, strategic development factor, competitive factor.

Political Factor. As national representatives, as the power center of government has a dual identity: It is in the organization and implementation of institutional innovation, not only to reduce transaction costs to achieve social motivation will maximize the total output, and always get the maximum monopoly rents. Thus, maximizing the rulers and its group structure and ownership of monopoly rents drop Exists between an effective system of low transaction costs, promote economic growth and lasting punch Sudden, it reflects the way the supply dominated Institutional Change in Institutional Change and systems Choose between conflict. A state-owned enterprise are government-owned or government-controlled economic entities, including the government by its ownership of the direct control of business, government, through its state-owned enterprise directly or indirectly holds a majority stake in the business and government to hold a small stake, though it can be effectively controlled enterprise. Since the state is the main owner or controller of state-owned enterprises, the government appoints an agent to perform its government's intention is very common practice. In the Loyalty Program Partnerships Construction and implementation process, a business, especially state-owned companies to make the decision whether to join the Loyalty Program Partnerships, government are often subject to factors. Partly because the government needs to conduct business to join the international coalition to win the short-term performance, on the other hand the government needs to increase local revenue through this behavior of enterprises.

Economic Factor. In the construction and implementation of the Loyalty Program Partnerships process, the chief businesses and companies want to join the alliance can derive economic benefits. Chief enterprises in Loyalty Program Partnerships expect to bring more customers, these customers from other franchisees. Increase revenue by expanding customer groups throughout the Union. Meanwhile, the chief companies can also enhance earnings by charging fees from franchisees. For franchisees, the hand can enhance the overall image of their enterprises by adding big companies Loyalty Program Partnerships; on the other hand, you can also get more customers from chief business groups. According to business expectations for the benefits of Loyalty Program Partnerships can be divided into single economic benefits and comprehensive benefits. In general, the main goal is to achieve Loyalty Program Partnerships mutual product integration mutual right, therefore, integral number s of channels a single integral benefits the Union, other issues such as corporate social image, competitive advantage and other comprehensive benefits constitute Loyalty Program Partnerships. Single benefit or not to get league has a crucial role, often become the criteria to judge success or failure of the Union; comprehensive benefits not have this importance, it belongs to the deputy benefit category. Of course, different point's coalition may have different expectations of benefits, such as increased integration approach, to provide customers with complementary services, the content of this league single-effective and comprehensive benefits transfer will occur accordingly. Loyalty Program Partnerships diversity benefit, to benefit distribution integration alliance adds a lot of uncertainty, increasing the difficulty of optimizing allocation.

Strategic Development Factor. Strategic Alliance has been recognized as contemporary global business development strategy fastest and most economical way, and is considered modern enterprises to improve their competitiveness in international markets in an effective form. Companies achieve growth through strategic alliances, often thanks to the strategic partnership between the complementary resources, sharing risk and cost factors. For some companies Loyalty Program Partnerships is a new form of strategic alliances. In existing Loyalty Program Partnerships, both inter-industry Loyalty Program Partnerships formed between the airlines, including cross-industry Loyalty Program Partnerships by the airlines, hotels and car rental companies constituted. You can achieve the optimal allocation of resources through the sharing of resources between the business integration with industry alliances, and through the cross-industry alliance between complementary products and services, to expand and enhance customer service. With the development of economic globalization, the world economy in all sectors and areas of mutual 
promotion worldwide, global trade, production, investment, finance and research and development, etc. have been developed in terms of size, depth and breadth. Chinese enterprises through the integration of large international companies to join the Union quickly into global development strategy, this approach will undoubtedly strategic development of enterprises provides a new way. Strategic development is a very important driving factor of Loyalty Program Partnerships.

Competitive Factor. With the growing competition in the market, companies expect to seek alliances to enhance their competitive advantage. Loyalty Program Partnerships as an innovative organizational relation, the overall objective is to enhance the company's competitive advantage, get more profit and achieve win-win cooperation between enterprises. In the specific implementation of the Loyalty Program Partnerships, horizontal alliances can solve the problem of the scale, and vertical alliances to solve the problem is lack of resources and other complementary products. Use of Loyalty Program Partnerships strategy alliance organization, you can more easily obtain the economic benefits of these two aspects. Chinese enterprises with good conditions for the implementation of the Loyalty Program Partnerships to take outside this resource extraction, mutually beneficial ways of cooperation so as to achieve economies of scale are very feasible. First of all, sharing enterprise customers can bring their business range growth, cooperation and synergies so that their mutual border market integration, to further expand the market space for development of Loyalty Program Partnerships. Secondly, the industry integration through the establishment of alliances, enterprise resource integration, to be fully utilized, the unit cost reduction, efficiency improvement. Finally, Loyalty Program Partnerships make it easier to obtain information between enterprises, especially cross-industry alliance enterprise integration, lower cost of customer information obtained from other companies, richer content, providing a more competitive edge.

\section{Conclusion}

Companies are increasingly forming Loyalty Program Partnerships as a means improving their competitive position through achieving marketing benefits and reducing costs. However, there are a number of factors which have to be given serious consideration by those companies contemplating the alliance strategy. This research has found four factors driving the company construct or join in the Loyalty Program Partnerships, Political factor is a special factor in China because of the special relationship between government and corporate, Economic factor in the main factor drive the companies join alliance, Strategic development factor is very important factor to make sure the company developed sustainability, Competitive factor Ensure that enterprises occupy a place in existing markets.

\section{Acknowledgements}

This paper is supported by National Natural Science Foundation for Youth of Shaanxi Province Science and Technology Hall (2013JQ9006), Social Science Foundation of Shaanxi Province (2015R018) and Foundation of Ministry of Education of China for Youth (13YJC630014)

\section{References}

[1] Lemon K N, Wangenheim F V. The reinforcing effects of loyalty program partnerships and core service usage: a longitudinal analysis, J. Journal of Service Research. 11 (2009) 371-393.

[2] Schumann J H, Wünderlich N V, Evanschitzky H. Spillover effects of service failures in coalition loyalty programs: the buffering effect of special treatment benefits, J. Journal of retailing. 90 (2014) 111-118.

[3] Yi I G, Jeong H M, Choi W, et al. Human dynamics of spending: Longitudinal study of a coalition loyalty program, J. Physica A: Statistical Mechanics and its Applications. 410 (2014) 391-398. 
[4] Lee M Y, Lee A S, Sohn S Y. Behavior scoring model for coalition loyalty programs by using summary variables of transaction data, J. Expert Systems with Applications. 40 (2013) 1564-1570.

[5] Goh K, Uncles M. The benefits of airline global alliances: an empirical assessment of the perceptions of business travelers, J. Transportation Research Part A: Policy and Practice. 37 (2003) 479-497.

[6] Lazzarini S G. The impact of membership in competing alliance constellations: Evidence on the operational performance of global airlines, J. Strategic Management Journal. 28 (2007) 345-367.

[7] Morrish S C, Hamilton R T. Airline alliances-who benefits? J. Journal of Air Transport Management. 8 (2002) 401-407.

[8] Bissessur A, Alamdari F. Factors affecting the operational success of strategic airline alliances, J. Transportation. 25 (1998) 331-355.

[9] Peng Li. Factors affecting consumer involvement airline alliance, J. Technology Information. 4 (2014) 113-114.

[10]Chaoran Chen. Discussion banks credit card loyalty program of Chinese commercial bank, J. Chinese Foreign. 4 (2014) 35. 